\title{
Individual and structural challenges in doctoral education : An ethical perspective
}

Roos, Liana

2021

Roos , L , Löfström , E \& Remmik , M 2021 , ' Individual and structural challenges in doctoral education : An ethical perspective ', International Journal of Doctoral Studies, vol. 16 , pp. 211-236 . https://doi.org/10.28945/4738

http://hdl.handle.net/10138/340818

https://doi.org/10.28945/4738

cc_by_nc

publishedVersion

Downloaded from Helda, University of Helsinki institutional repository.

This is an electronic reprint of the original article.

This reprint may differ from the original in pagination and typographic detail.

Please cite the original version. 


\title{
International Journal of Doctoral Studies
}

An Official Publication

of the Informing Science Institute

InformingScience.org

IJDS.org

Volume 16, 2021

\section{INDIVIDUAL AND STRUCTURAL CHALLENGES IN Doctoral Education: AN ETHICAL Perspective}

\author{
Liana Roos* \\ Erika Löfström \\ Marvi Remmik \\ * Corresponding author
}

University of Tartu, Tartu, Estonia

liana.roos@ut.ee

University of Helsinki, Helsinki, Finland

erika.lofstrom@helsinki.fi

University of Tartu, Tartu, Estonia

marvi.remmik@ut.ee

\section{ABSTRACT}

Aim/Purpose

Background

Methodology

Contribution
The study set out to understand the challenges doctoral students experience at different systemic levels of doctoral education through the perspective of ethical principles.

Doctoral students experience various challenges on their journey to the degree, and as high dropout rates indicate, these challenges become critical for many students. Several individual and structural level aspects, such as student characteristics, supervisory relationship, the academic community as well national policies and international trends, influence doctoral studies, and students' experiences have been researched quite extensively. Although some of the challenges doctoral students experience may be ethical in nature, few studies have investigated these challenges specifically from an ethics perspective.

The study drew on qualitative descriptions of significant negative incidents from 90 doctoral students from an online survey. The data were first analyzed using a reflexive thematic analysis, and then the themes were located within different systemic levels of doctoral studies: individual (e.g., doctoral student, the individual relationship with supervisor) and structural (e.g., the institution, faculty, academic community). Finally, the ethical principles at stake were identified, applying the framework of five common ethical principles: respect for autonomy, benefiting others (beneficence), doing no harm (non-maleficence), being just (justice), and being faithful (fidelity).

Understanding doctoral students' experiences from an ethical perspective and locating these among the systemic levels of doctoral studies contributes to a better understanding of the doctoral experience's complexities. Ethical considerations should be integrated when creating and implementing procedures, rules, and policies for doctoral education. Making the ethical aspects visible will

Accepting Editor Jenna M Weglarz-Ward | Received: November 26, 2020| Revised: February 8, March 7, March 23, 2021 | Accepted: March 24, 2021.

Cite as: Roos, L., Löfström, E., \& Remmik, M. (2021). Individual and structural challenges in doctoral education: An ethical perspective. International Journal of Doctoral Studies, 16, 211-236. https://doi.org/10.28945/4738

(CC BY-NC 4.0) This article is licensed to you under a Creative Commons Attribution-NonCommercial 4.0 International License. When you copy and redistribute this paper in full or in part, you need to provide proper attribution to it to ensure that others can later locate this work (and to ensure that others do not accuse you of plagiarism). You may (and we encourage you to) adapt, remix, transform, and build upon the material for any non-commercial purposes. This license does not permit you to use this material for commercial purposes. 
Findings

Recommendations for Practitioners

Recommendations for Researchers

Impact on Society

Future Research

Keywords also allow universities to develop supervisor and faculty training by concretely targeting doctoral studies aspects highlighted as ethically challenging.

In doctoral students' experiences, structural level ethical challenges out-weighed breaches of common ethical principles at the individual level of doctoral studies. In the critical experiences, the principle of beneficence was at risk in the form of a lack of support by the academic community, a lack of financial support, and bureaucracy. Here, the system and the community were unsuccessful in contributing positively to doctoral students' welfare and fostering their growth. At the individual level, supervision abandonment experiences, inadequate supervision, and students' struggle to keep study-related commitments breached fidelity, which was another frequently compromised principle. Although located at the individual level of studies, these themes are rooted in the structural level. Additionally, the progress review reporting and assessment process was a recurrent topic in experiences in which the principles of non-maleficence, autonomy, and justice were at stake.

Going beyond the dyadic student-supervisor relationship and applying the ethics of responsibility, where university, faculty, supervisors, and students share a mutual responsibility, could alleviate ethically problematic experiences.

We recommend that further research focus on experiences around the ethics in the progress reporting and assessment process through in-depth interviews with doctoral students and assessment committee members.

Dropout rates are high and time to degree completion is long. An ethical perspective may shed light on why doctoral studies fail in efficiency. Ethical aspects should be considered when defining the quality of doctoral education.

A follow-up study with supervisors and members of the academic community could contribute to developing a conceptual framework combining systemic levels and ethics in doctoral education.

doctoral students' experiences, ethical principles, ethical challenges, doctoral education, systemic perspective

\section{INTRODUCTION}

Doctoral studies have gained increased attention in research focusing on matters such as teaching, employment and careers, writing and research, student-supervisor relationships, the doctoral student experience, and doctoral program design (Jones, 2013). The efficiency of doctoral studies has been identified as a challenge. Dropout rates are high and the amount of time needed to complete studies successfully is relatively long. Only half of the doctoral students complete their studies within a nominal study period (Jairam \& Kahl, 2012).

In Estonia, the context of this study, the success rate is even lower. Despite educational and institutional policies, $60 \%$ of $\mathrm{PhD}$ students fail to graduate within the nominal period of studies of four years or drop out of their doctoral program (Vassil \& Solvak, 2012). Many PhD students' progress is too slow for graduation in the nominal time due to occupational responsibilities not related to their studies (Ots et al., 2012). As much as $80 \%$ of Estonian doctoral students work full-time or part-time outside the university (Eamets et al., 2014). Research addressing the reasons for dropping out of studies in Estonia has found students' personal factors and supervision, the institution, and the wider academic community to be influencing factors (Leijen et al., 2016). Structural problems have been identified as the primary concern in Estonian doctoral education (Vassil \& Solvak, 2012). 
Doctoral education can be seen as a hierarchic interactive socially-embedded system constituted by a range of influencing aspects on different levels - a perspective adopted by some authors previously (e.g., Cornér, 2020; Lovitts, 2005; McAlpine \& Norton, 2006). For example, Lovitts' (2005) model of factors influencing degree completion included individual resources (personality, motivation, intelligence, knowledge, thinking styles), microenvironment (supervisor, peers, department, location), and macroenvironment (culture of the discipline and graduate education). McAlpine and Norton (2006) additionally acknowledged national and international trends like globalization and changed technical and economic conditions as a crucial systemic level influencing the doctoral experience. Recently, Cornér (2020) showed how diverse systemic levels like the supervisory relationship, researcher communities, and institutions offered different sources and forms of support in doctoral students' interplay with their environment. Collectively, these studies outline the importance of considering diverse systemic levels when investigating doctoral experiences.

It has been suggested that, for doctoral students, the journey towards completing their degree is emotionally and intellectually intense, involving complex challenges (Jones, 2013; Weise et al., 2020), which can be embedded in different systemic levels ranging from individual to structural (Cornér et al., 2019). Some of the challenges experienced during doctoral studies may be ethical in nature.

The present study draws on five common ethical principles; namely, respect for autonomy, doing no harm (non-maleficence), benefiting others (beneficence), being just (justice), and being faithful (fidelity) (cf. Kitchener, 1985, 2000). These principles are familiar to academia through a plethora of codes of conduct, including the European Code of Conduct for Research Integrity (European Federation of Academies of Sciences and Humanities [ALLEA], 2017) and the Declaration of Helsinki (WMA, 2013). Respect for autonomy equates to individuals' right to decide how to live their lives, the right to make decisions concerning their lives, and the right to self-determination. Non-maleficence involves avoidance of psychologically, physically, economically, or socially harmful activities. The principle of beneficence means making a positive contribution to another's welfare, being responsive to another's needs, helping, and promoting others' personal growth. Justice implies fairness, impartiality and equality, and fair dissemination of resources, such as information or time. Fidelity equates to keeping promises and being loyal and truthful. These five principles have been applied in research on counseling (Kitchener, 1985, 2000), student affairs (Holzweiss \& Walker, 2016; Janosik et al., 2004), as well as on doctoral supervision (Löfström \& Pyhältö, 2012, 2014, 2015, 2017, 2020).

Thus far, studies have investigated ethical challenges in the context of supervision and the supervisory relationship (Brown \& Krager, 1985; Halse \& Bansel, 2012; Löfström \& Pyhältö, 2012, 2014, 2015, 2017, 2020; Rosenberg \& Heimberg, 2009). The supervisory context influences how doctoral students view academic integrity and learn and adopt ethical values and practices (Gray \& Jordan, 2012). Still, supervision does not occur in isolation and is influenced by the scholarly community's values and traditions. Higher education institutions shape ethical relations, and their ethical standards are articulated in leadership, and educational practices and research (Prisacariu \& Shah, 2016). Participating in the academic community, observing faculty and peers contributes in fundamental ways to the development of doctoral students' ethical norms (Alfredo \& Hart, 2011; Anderson \& Louis, 1994; Gray \& Jordan, 2012), which is vital for their future responsibilities as academics, supervisors or other professions outside academia.

Considering doctoral education as a moral responsibility (Halse \& Bansel, 2012; Prisacariu \& Shah, 2016) and using Estonian doctoral studies as an example, this paper offers insights into the challenges doctoral students are experiencing at diverse systemic levels of studies from an ethical perspective. A systematic understanding of how ethics contributes to doctoral studies is still limited. Combining the concept of doctoral education as a multilevel system, the framework of the ethical principles and ethical analysis, Löfström and Pyhältö (2021) suggested a theoretical model for conceptualizing ethics in supervision. They illustrated how emerging dilemmas in the supervisory relationship in described ethical domains could be nested at the individual, local researcher community, 
Ethical Perspective on Challenges in Doctoral Education

institutional, and (inter)national levels. This study draws on ethical principles in a similar vein and locates the identified ethical issues to individual and structural levels in a systemic outlook, contributing with empirical research on the systemic perspective from the doctoral students' perspective. An ethical perspective may shed light on why doctoral studies fail in efficiency. Furthermore, tracing ethical challenges on doctoral studies varied systemic levels is important for decision-makers, doctoral students, supervisors, research teams, and doctoral programs, enabling addressing ethical challenges at the appropriate level - where they emerge.

The following literature review describes in greater detail the systemic and ethical aspects of doctoral experience.

\section{LITERATURE REVIEW}

\section{CHALLENGES ON INDIVIDUAL AND STRUCTURAL LEVEL OF DOCTORAL EDUCATION INFLUENCING THE DOCTORAL EXPERIENCE}

Researchers have exposed an isolated and harrowing journey from admission to graduation, where doctoral students faced complex challenges (Jones, 2013), located among different systemic levels from individual to structural (Cornér, 2020; Cornér et al., 2019). These levels - individual and structural - were mutually influencing, and several aspects of them affected doctoral studies (Bair \& Haworth, 2004; Castelló et al., 2017). A clear-cut distinction between individual and structural level aspects was not always possible, as doctoral practices and arrangements were context-specific, mirroring the interweaving nature of the participants' individual, social and cultural behaviors and the academic community (Cumming, 2010). Furthermore, as Castelló et al. (2017) observed, some of the factors frequently considered as personal were genuinely related to contrasts between doctoral students' individual needs and resources and institutional capacity and practices.

Several studies have investigated how student-related aspects shape a successful doctorate. These aspects included doctoral students' motivation and the characteristics of goal-directedness and the concept of self (Bair \& Haworth, 2004); intelligence, knowledge, thinking style (Lovitts, 2005); and also, competencies (Cornér et al., 2019; Leijen et al., 2016). Weise et al. (2020) found that reassessment of the competencies in the research process due to the pressure to publish was one of the frequent challenges that doctoral students experienced, and that responding to this challenge required "a high tolerance for frustration and the ability to manage negative feelings such as insecurity, rejection, and failure" (p. 15). Also, health and family influenced doctoral students' personal resourcefulness and thus their studies (Katz, 2018; McAlpine et al., 2012) and wellbeing (Cornér et al., 2017; Pyhältö et al., 2012a). High workloads and difficulties in balancing research work and private life led to exhaustion, stress, and, consequently, the attrition of motivation for doing doctoral studies (Castelló et al., 2017; Leijen et al., 2016; Pyhältö et al., 2012a). Doctoral students also experienced feelings of guilt, as family members received less attention due to doctoral studies' workload (Cornwall et al., 2019).

According to Lee (2008), supervision had the most powerful impact on the doctoral study process. Several authors have previously reported how the quality of supervision influenced the duration of studies, the well-being of doctoral students (Peltonen et al., 2017; Pyhältö et al., 2012a; Weise et al., 2020), their satisfaction with studies, and the development of their competencies (Peltonen et al., 2017; Pyhältö et al., 2012a). Change of supervisors, unmet expectations for communication and guidance, as well as conflicts between supervisors, led to supervisor-related stress (Cornwall et al., 2019). Accordingly, the relationship with the supervisor was one of the main challenges for doctoral students (Corcelles et al., 2019).

While many researchers considered supervisors' support critical for doctoral success, De Clercq et al. (2019) noted that it was not the only determinant of the doctoral experience. Prior research showed that supervision had both structural and individual aspects: on the one hand, supervision comprised an individual relationship between supervisor and student, and on the other hand, institutional and 
disciplinary practices and traditions influenced it (Murphy et al., 2007). Therefore, authors have emphasized the necessity to consider the academic community's social context (Cornér et al., 2019; McAlpine et al., 2012). Researchers have highlighted the importance of doctoral students' socialization into the research community (Cornwall et al., 2019; McAlpine et al., 2012; Sala-Bubaré \& Castelló, 2017) for the success of studies (Hlebec et al., 2011) as well as for the socio-psychological wellbeing of doctoral students (Cornér et al., 2017; Hlebec et al., 2011; Peltonen et al., 2017). Studies have pinpointed negative experiences related to the researchers in the nearest academic community (Corcelles et al., 2019) and a lack of departmental interest and support (McAlpine et al., 2012), as well as the importance of the sense of belonging and worth for doctoral students to connect with their institution (Teeuwsen et al., 2014). Consequently, identification with a scholarly community, loneliness, and a non-constructive atmosphere were the main challenges doctoral students experienced (Pyhältö et al., 2012b).

Alongside, the organization of doctoral studies, including program structure, funding, and assessment directives, entailed challenges in doctoral experience in earlier research. Several studies reported that financial resources were crucial for a successful doctorate (Corcelles et al., 2019; Cornér et al., 2019; Cornwall et al., 2019; Leijen et al., 2016; Vassil \& Solvak, 2012). For example, Corcelles et al. (2019) found that negative experiences related to finances were most frequent for doctoral students in social sciences and those working outside the university. From the perspective of supervisors, Cornér et al. (2019) identified insufficient funding as one of the most prevalent challenges. In a recent study by Cornwall et al. (2019), doctoral students experienced conflicts between their expectations and their actual experiences of doctoral studies and stress related to the uncertainty of the process associated with doctoral studies' deficient structure. From the viewpoint of supervisors, Cornér et al. (2019) reported experienced shortcomings in doctoral education structure, such as the recruitment process, the content of provided courses, and the lack of administrative support, as dominant challenges. Other authors (see Eamets et al., 2014; Leijen et al., 2014, Mewburn et al., 2014) have discussed the challenges related to doctoral students' progress review reporting and assessment, which were "often considered formal and insignificant for guiding their research" (Leijen et al., 2014, p. $139)$.

This section provided an overview of the literature related to aspects influencing doctoral experience on different systemic levels of doctoral education, including challenges doctoral students experience on these systemic levels. The evidence presented indicates that challenges can be related to all systemic levels of doctoral studies. Challenges in doctoral experiences need attention, as these may cause delays, affect the quality and contribute to considerations about dropping out of the studies (Katz, 2018). However, as suggested in the introduction, some of the challenges may have an ethical nature. Therefore, we next address the ethical aspects of doctoral education.

\section{ETHICS IN DOCTORAL EDUCATION}

While some authors have previously emphasized higher education institutions' responsibility for creating ethical learning environments that prepare future professionals and leaders (e.g., Couch \& Dodd, 2005), others have stated that higher education quality cannot be defined without considering ethical and moral aspects (e.g., Prisacariu \& Shah, 2016). Furthermore, Halse and Bansel (2012) stated that the attempts to conceptualize doctoral education practices without moral and ethical considerations are bound to fail.

Nevertheless, the ethical aspects of doctoral studies have been the focus of prior studies rather infrequently. Some of them have emphasized supervisors' central role in shaping doctoral students' understanding of academic ethics. For example, the now classical, large-scale survey by Anderson and Louis (1994) established that doctoral students adopted academic norms by observing seniors, including supervisors, and participating in the academic community. Gray and Jordan (2012) found that 
Ethical Perspective on Challenges in Doctoral Education

supervisors' personal involvement significantly impacted students' attitudes towards academic integrity. However, they also noticed that as students' knowledge about academic integrity and research ethics increased, they began to question their supervisors as ethical exemplars (Gray \& Jordan, 2012).

Other authors have highlighted ethical issues around relationships, especially when there were differences in knowledge, status, and power. Due to the supervisory relationship's centeredness in the doctoral experience, ethical challenges in supervisory relationships have been the primary focus of previous studies. Investigating both doctoral students and supervisors, Löfström and Pyhältö $(2015,2017)$ showed that both parties experienced the same ethical challenges, but their views and focuses differed, which made it challenging to identify a common denominator. While supervisors highlighted mainly exploitation, misappropriation, and dual relationships as ethical dilemmas (Löfström \& Pyhältö, 2017; Rosenberg \& Heimberg, 2009), doctoral students emphasized the lack of a collective culture, abandonment, inadequate supervision, and inequality (Löfström \& Pyhältö, 2017). Contrasting expectations towards doctoral studies were one reason behind the varied perceptions of emerging challenges. A study by Löfström and Pyhältö (2015) demonstrated that supervisors approached doctoral studies from a systemic and work-based level in contrast to doctoral students who perceived their studies as an individual experience in which the nature of the supervision relationship defined much of their doctoral study experience.

However, researchers have also found analyzing ethical challenges at the dyadic supervisor-student level to be insufficient, as the values, attitudes, norms, and practices expressed through the dyadic relationship were often rooted in the traditions and practices of the academic community, from which they transferred to the actions of individuals (Löfström \& Pyhältö, 2012). Therefore, McAlpine (2013) underlined the importance of shared institutional responsibility. Rogers-Shaw and CarrChellman (2018) used the concept of ethics of care to explore the relationships doctoral students experienced and indicated the importance of care in doctoral education. Similarly, McAlpine et al. (2012) suggested that instead of regulatory systems, the ethics of care in doctoral educations pedagogics must be implemented. However, Halse and Bansel (2012) considered ethics of care insufficient. They conceptualized the ethics of responsibility in the doctoral process as a learning alliance, where all parties, including doctoral students, supervisors, other faculty members, and administrative staff across the university, shall jointly contribute to the doctoral experience (Halse \& Bansel, 2012).

As pointed out in the introduction, ethical principles such as respect for autonomy, non-maleficence, beneficence, justice, and fidelity are familiar to the academic community through the codes of conduct guiding their rights and responsibilities in the research and relationships in the academy. In the context of doctoral education, researchers have previously applied these principles investigating doctoral supervision (e.g., Brown \& Krager, 1985; Löfström \& Pyhältö, 2012, 2014, 2015, 2017, 2020). Brown and Krager (1985) regarded respecting differing viewpoints and enabling students' choices as a faculty responsibility in respecting autonomy. Further findings showed that the lack of autonomy hindered doctoral students from developing independence and their own researcher identity (Johnson et al., 2010; Löfström \& Pyhältö, 2015). Concerning the principle of non-maleficence, Brown and Krager (1985) suggested avoiding excessive demands and a competitive climate and responding to students' pressures. Breaches of the principle took the form of exploitation, abuse, and misuse of power in prior research (Löfström \& Pyhältö, 2012, 2017). Corresponding with the principle of beneficence, Cornér et al. (2017) indicated supervisors' contribution to doctoral students' wellbeing by distributing their workload, providing information, and assisting them in selecting courses. Failing to support doctoral students' development and wellbeing compromised beneficence, confirmed by the findings of Löfström and Pyhältö (2017), who noted that while breaches of non-maleficence typically involved more active and directly harmful acts, breaches of beneficence tended to constitute a failure to do what is good or right. With regard to the principle of justice, prior research reported doctoral students to appreciate the fair allocation of opportunities and responsibilities in the supervisory relationship (Löfström \& Pyhältö, 2012, 2014). However, the reasoning based on which supervisors made decisions was not always transparent for students and contributed therefore to experiences 
of unfair or unequal treatment (Löfström \& Pyhältö, 2012, 2014). Brown and Krager (1985) interpreted the principle of fidelity in the context of doctoral education as maintaining values in faithful collaboration. In prior research, breaches of fidelity involved the inability of an individual or the system to provide support which the doctoral student may reasonably expect (Löfström \& Pyhältö, 2012, 2017). However, doctoral students also reported struggling with keeping promises and commitments in previous studies (Löfström \& Pyhältö, 2014).

To conclude, prior research has provided insights into numerous influential features of doctoral experience, including challenges on different systemic levels. However, these challenges' ethical nature is less examined. The limited prior research on ethical aspects in doctoral experience has not often recognized the interweaved multilevel nature of doctoral education and focused mainly on the dyadic supervisory relationship. This study aims to fill the gap.

\section{METHODOLOGY}

\section{AIM OF THE STUDY}

Drawing upon the two previously explicated strands of research on doctoral studies, namely the ethical aspects and the systemic approach to understand doctoral experiences, we designed this study to identify the ethical nature of the challenges doctoral students experience at both individual and structural levels of doctoral education. The following research question was addressed: What kind of challenges do doctoral students experience that breach common ethical principles, and with which systemic levels of doctoral studies are the challenges associated?

In the next sections, we briefly describe the context of our study as well as the procedures and methods used in this study.

\section{CONTEXT}

In Estonia, doctoral students undertake a publicly funded, structured doctoral training program with a nominal study period of 4 years. Although the studies' emphasis is on research and writing a dissertation (180 ECTS credits, European Credit Transfer System), the students also participate in compulsory and optional coursework (60 ECTS). The doctoral dissertation can be a monograph or an article-compilation, including a summary and at least three peer-reviewed articles. The defense of the doctoral dissertation takes place as a public, academic discussion with an opponent.

A progress review committee, consisting of at least three faculty members who hold doctoral degrees, assesses yearly and evaluates, using ECTS credits, doctoral studies' progress. Besides the coursework, credits are awarded for publications, conferences and seminars, and other research activities related to the doctoral thesis. The faculty or institute defines the exact criteria for awarding credits. Before the public progress review meeting, the doctoral student submits a progress review report documenting the curriculum's fulfillment and elaborating on activities for the next review period. For a positive assessment, the individual study plan's fulfillment to the extent of at least $50 \%$ is required.

Based on the outcomes of the doctoral progress review assessment, doctoral study stipends are renewed. Since 2018, full-time students on state-commissioned study places with positive progress review results receive a monthly allowance of $€ 660$, which is below the average monthly gross wage of $€ 1407$ in Estonia (see Statistics Estonia, 2020). Some universities currently provide students who have completed $100 \%$ of their individual study plan with an additional performance stipend of $€ 400$. Around $80 \%$ of doctoral students work full or part-time outside the university (Eamets et al., 2014).

\section{DATA COLLECTION}

Qualitative data from a larger survey concerning doctoral students' experiences were used to answer the research question. Open-ended prompts on significant negative events in doctoral studies from 
Ethical Perspective on Challenges in Doctoral Education

the Doctoral Experience Survey (Cornér et al., 2018; Peltonen et al., 2017; cf. also Pyhältö et al., 2009; Pyhältö et al., 2011) were used. The prompts were formulated as follows: The most negative event or experience from the beginning of my doctoral journey until now was when ... This event or experience was important to me because ... At that time, I felt ... These allowed the identification of ethically challenging experiences ranging from ordinary to extreme events. Respondents could describe their experiences in a freeform response using their own words and without a word limit. Other survey themes interested in doctoral studies, turning points in doctoral studies, research environments, supervision and collaboration, and career plans. The interpretation of these results is the object of a further study.

As the data were collected online, the length of descriptions on experienced significant negative incidents varied from shorter notes about having no negative experiences to up to over 300-word vignettes about various challenging situations, feelings experienced, and the meanings given to these experiences. On several occasions, a combination of situations was described, but generally, this was not the case. All vignettes were collected as one textual file of 14 pages of participant-generated data (using font Times New Roman, size 12, double spacing).

\section{PARTICIPANTS}

The survey was carried out in a research-intensive university in Estonia. The call to participate in the research was circulated to doctoral students at the university, along with an explanation of the study's objectives through the department administrators. Students were not given incentives to participate in the study, participation was voluntary and based on informed consent.

In total, qualitative descriptions of significant negative events were received from 90 doctoral students from social science and humanities $(\mathrm{n}=50)$ and natural sciences, including technology and medicine $(n=40)$. The doctoral students were at various stages of their studies, although half had reached or exceeded their final nominal study year. Seventy-three percent of participants were women, the majority of participants were over 30 years old. These characteristics reflect the socio-demographics of the $\mathrm{PhD}$ student population at the university under study reasonably well. Due to the research topic's sensitivity and to protect the participants' anonymity, no further details about gender, year of studies, or field of study are provided. This is also why we deliberately use the singular 'they' when referring to participants. Any reference to the respondents' demographics or any third parties mentioned were neutralized in the quotations used to illustrate the themes. The number at the end of each quotation refers to the participant data in our database and can track the excerpt in the broader data set.

As the current study drew on qualitative data, the aim was to provide in-depth explanations and explore meanings rather than present representative data or generalize our findings. According to Braun and Clarke (2013), a sample size of 10-50 participants is suggested for smaller research projects when collecting data via participant-generated text and using thematic analysis, as was the case in this study.

\section{DATA ANALYSIS}

To make sense of the data, several approaches were used at different stages of data analysis. We aimed to "report experiences, meanings and the reality of the participants" (Braun \& Clarke, 2006, p. 81) and identify patterns of shared meaning (Braun \& Clarke, 2020). Therefore, we used reflexive thematic analysis (Braun \& Clarke, 2019, 2020), as we consider this consistent with the aim and research question of the study. In line with a constructionist framework, we sought to perceive the structural conditions associated with individual experiences (cf. Braun \& Clarke, 2006).

We followed the six phases of thematic analysis (Braun \& Clarke, 2006): (1) familiarizing ourselves with the data; (2) generating initial codes; (3) searching for themes; (4) reviewing themes; (5) defining and naming themes; and (6) producing the report. The iterative process of data coding, theme development, and revision was undertaken. First, all vignettes were read several times, and subjected to the question: does it describe an ethical challenge? The interpretations were discussed among the authors, 
ending up with 59 units where ethics was at risk. Next, the initial iterative, open coding process was carried out by one of the authors, aiming to recognize items that may form the basis of themes. At this stage, the data analysis was inductive, being directed by the content of the data, although reflexively engaged with some theoretical assumptions about ethics, as thematic analysis "can never be conducted in a theoretical vacuum" (Braun \& Clarke, 2020, p. 10). All items were read several times, identifying relevant segments capturing an observation or aspect relevant to the research question. The segment of coding ranged from a single word to a full vignette. These were labeled with a summative essence-capturing word or phrase. Several coding rounds were carried out to facilitate the development of more latent codes. After initial iterative coding, the codes were discussed with other authors to enhance the credibility. During peer discussions, we looked for meanings rather than specific keywords, as the participants were not directly asked to describe ethically challenging experiences, but these were identified as part of descriptions of negative experiences. In line with the chosen reflexive thematic analysis approach, rather than aspire to a coding consensus, this was a collaborative and reflexive process (Braun \& Clarke, 2019, 2020).

All codes and data extracts were then brought together for the next stage of analysis. The phase of identifying potential themes was again initially carried out by one of the authors, who examined the codes and arranged and rearranged them to generate initial themes; that is, entities capturing a reoccurring essence in the data (Braun \& Clarke, 2016). The coded data extracts were reviewed for each theme several times, sometimes revealing the need for some changes in initial themes. The iterative theme development was followed by writing brief descriptions capturing each theme's central concept to sharpen the analytic focus (Braun et al., 2016). The themes and their names and descriptions were then discussed and reviewed among all authors. Some of the initial themes were combined; for example, after a discussion, the initial theme of authorship issues was added to the theme of exploitation, as this was judged to describe the ethical challenge in the theme best. We ended up with 16 themes in total (see Table 1).

Next, we located the themes within the individual level (e.g., related to the doctoral student or the individual's relationship with their supervisor) and structural level of doctoral studies (e.g., the institution, faculty, academic community). Finally, we identified the ethical principle compromised in the themes, deductively applying the framework of common ethical principles described in previous chapters. For example, the theme of Lack of support from the academic community was identified as a Structural level challenge because the student experience appeared to boil down to the academic community failing to support doctoral students in their studies and, therefore, the ethical principle of beneficence was found to have been compromised.

Through reflexive thematic analysis (Braun \& Clarke, 2006, 2019, 2020), we generated five themes at the individual systemic level, namely (1) intolerance for differing opinions; (2) students' struggle to keep study-related promises; (3) inadequate supervision; (4) supervisor abandonment; and (5) exploitation; and ten themes at the structural level, namely (6) faculty members critique of students' independent choices; (7) lack of support from the academic community; (8) lack of financial support; (9) bureaucratic documentation; (10) perceived unfairness of the doctoral progress review process; (11) discriminating power hierarchies in academia when solving conflict situations; (12) favoritism; (13) detrimental atmosphere at the progress review assessment; (14) exploitation; and (15) peer competition for funding opportunities, as well as one theme at the individual/structural level: (16) disregarding students' wellbeing. Two of the themes were breaching the principle of autonomy, three of them the principle of fidelity and the principle of justice, and four the principle of beneficence and the principle of non-maleficence (see Table 1).

The trustworthiness of the analysis was ensured throughout the whole process, bearing consistently in mind the quality criteria, concept, and procedures of reflexive thematic analysis (Braun \& Clarke, 2020). We have provided explanations of methodology, outlined and described the analytic procedures. Between the iterative coding, theme generating, reviewing, and defining processes, the authors 
discussed the interpretations - the process was collaborative and reflexive in line with the chosen reflexive thematic analysis approach, where consensus coding and inter-rater reliability measures are against the qualitative values of the framework, "because meaning and knowledge are understood as situated and contextual, and researcher subjectivity is conceptualised as a resource for knowledge production" (Braun \& Clarke, 2020, pp. 7-8). We aimed to develop a rich analysis of the data, ensuring the themes represent the data and presenting the themes and exemplar quotes systematically (Table 1).

Table 1. Themes of ethical challenges in doctoral students' experiences

\begin{tabular}{|c|c|c|c|c|}
\hline $\begin{array}{l}\text { Themes } \\
\text { (no. of } \\
\text { events) }\end{array}$ & Description of the theme & Empirical examples & $\begin{array}{l}\text { Systemic } \\
\text { level }\end{array}$ & $\begin{array}{c}\text { Ethical } \\
\text { principle }\end{array}$ \\
\hline $\begin{array}{l}\text { Intolerance } \\
\text { for differing } \\
\text { opinions } \\
(n=4)\end{array}$ & $\begin{array}{l}\text { Doctoral students experienced not } \\
\text { being able to develop their own } \\
\text { ideas in their research and per- } \\
\text { ceived some discussions with su- } \\
\text { pervisors as intrusive. Additionally, } \\
\text { they felt they were not allowed to } \\
\text { criticize or have opposing views to } \\
\text { their supervisors. Disagreements } \\
\text { with supervisors threatened the fu- } \\
\text { ture collaboration. }\end{array}$ & $\begin{array}{l}\text { My supervisor accused me of } \\
\text { ruining the work of others. I } \\
\text { actually criticized the structure } \\
\text { of the article manuscript and } \\
\text { offered some solutions that, in } \\
\text { my opinion, would make it } \\
\text { more attractive. (45) }\end{array}$ & Individual & \multirow{2}{*}{ 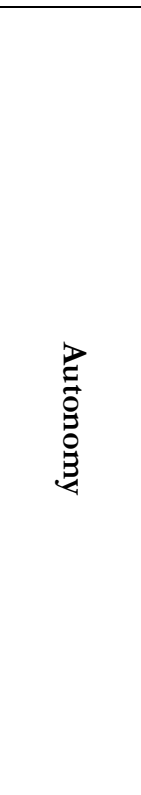 } \\
\hline $\begin{array}{l}\text { Faculty } \\
\text { members cri- } \\
\text { tique of stu- } \\
\text { dents' inde- } \\
\text { pendent } \\
\text { choices } \\
(n=2)\end{array}$ & $\begin{array}{l}\text { Students' independent choices re- } \\
\text { garding their research or studies are } \\
\text { being considered inadequate and } \\
\text { criticized by faculty members at the } \\
\text { progress review assessment, even } \\
\text { though these bad choices could } \\
\text { have been avoided through the } \\
\text { provision of timely support by } \\
\text { community members. }\end{array}$ & $\begin{array}{l}\text { I chose a conference and it } \\
\text { turned out to be unreliable. } \\
\text { (90) }\end{array}$ & Structural & \\
\hline $\begin{array}{l}\text { Disregarding } \\
\text { students' } \\
\text { wellbeing } \\
(\mathrm{n}=2)\end{array}$ & $\begin{array}{l}\text { Doctoral students experience burn- } \\
\text { out and other mental health prob- } \\
\text { lems, but these are not addressed. }\end{array}$ & $\begin{array}{l}\text { Fighting my depression takes } \\
\text { all of my strength at the mo- } \\
\text { ment and makes my everyday } \\
\text { life significantly difficult, not to } \\
\text { mention the doctorate. [I feel] } \\
\text { I have to choose between my } \\
\text { health and doctoral degree, as I } \\
\text { can't have both at the same } \\
\text { time. (73) }\end{array}$ & $\begin{array}{l}\text { Individual/ } \\
\text { Structural }\end{array}$ & \multirow{2}{*}{ 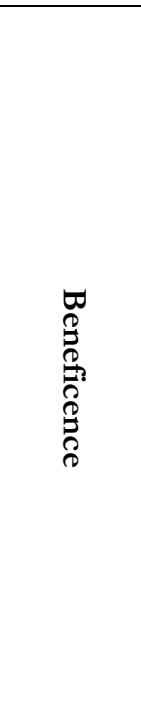 } \\
\hline $\begin{array}{l}\text { Lack of sup- } \\
\text { port from } \\
\text { the academic } \\
\text { community } \\
(n=8)\end{array}$ & $\begin{array}{l}\text { Doctoral students experienced situ- } \\
\text { ations where the faculty failed to } \\
\text { support and guide them when } \\
\text { needed (e.g. when struggling with } \\
\text { studies or making study-related } \\
\text { choices, lack of adequate supervi- } \\
\text { sion). They also described feelings } \\
\text { of not being part of the academic } \\
\text { community and isolation. }\end{array}$ & $\begin{array}{l}\text { There is no progress and no } \\
\text { one cares ... It makes me con- } \\
\text { stantly feel like I am all alone } \\
\text { in this. Thoughts of quitting. } \\
\text { (76) }\end{array}$ & Structural & \\
\hline
\end{tabular}




\begin{tabular}{|c|c|c|c|c|}
\hline $\begin{array}{l}\text { Themes } \\
\text { (no. of } \\
\text { events) }\end{array}$ & Description of the theme & Empirical examples & $\begin{array}{c}\text { Systemic } \\
\text { level }\end{array}$ & $\begin{array}{c}\text { Ethical } \\
\text { principle }\end{array}$ \\
\hline $\begin{array}{l}\text { Lack of fi- } \\
\text { nancial sup- } \\
\text { port }(n=5)\end{array}$ & $\begin{array}{l}\text { Low income for research leaves } \\
\text { doctoral students feeling worthless } \\
\text { and seeking additional income. } \\
\text { They expected reciprocal apprecia- } \\
\text { tion from the state and the institu- } \\
\text { tion for their input, which seems to } \\
\text { be lacking despite their efforts to } \\
\text { live up to what they perceive to be } \\
\text { the institution's expectations and } \\
\text { the government's rhetoric. }\end{array}$ & $\begin{array}{l}\text { As I found out my total in- } \\
\text { come for my work at the uni- } \\
\text { versity's laboratory, I obviously } \\
\text { needed to find additional in- } \\
\text { come. Research is clearly not } \\
\text { valued, as you cannot live on } \\
\text { research alone. (16) }\end{array}$ & & \\
\hline $\begin{array}{l}\text { Bureaucratic } \\
\text { documenta- } \\
\text { tion }(n=5)\end{array}$ & $\begin{array}{l}\text { When reporting their progress or } \\
\text { applying for scholarships or sti- } \\
\text { pends, doctoral students find this } \\
\text { documentation bureaucratic, time- } \\
\text { consuming, complicated and con- } \\
\text { tradictory to the inherent values of } \\
\text { academic growth. }\end{array}$ & $\begin{array}{l}\text { Applying for stipends is diffi- } \\
\text { cult and the amount of money } \\
\text { is too small to be able to attend } \\
\text { international conferences or } \\
\text { courses sufficiently. Every time } \\
\text { when applying, it feels as if } \\
\text { they don't want the doctoral } \\
\text { students to be able to socialize } \\
\text { with international colleagues } \\
\text { (9) }\end{array}$ & & \\
\hline $\begin{array}{l}\text { Students' } \\
\text { struggle to } \\
\text { keep study- } \\
\text { related } \\
\text { promises } \\
(\mathrm{n}=5)\end{array}$ & $\begin{array}{l}\text { Experiences where the need to bal- } \\
\text { ance work and doctoral studies led } \\
\text { to the struggle to keep promises } \\
\text { and meet the expectations of the } \\
\text { doctoral program, supervisors and } \\
\text { oneself. }\end{array}$ & $\begin{array}{l}\text { I didn't have enough time for } \\
\text { my doctoral studies due to the } \\
\text { workload [outside the univer- } \\
\text { sity]. At the beginning of my } \\
\text { studies, I was very motivated to } \\
\text { work on my dissertation, but } \\
\text { the motivation faded with } \\
\text { tiredness and lack of time. } \\
\text { (15) }\end{array}$ & \multirow{3}{*}{ Individual } & \multirow{3}{*}{$\frac{1}{2}$} \\
\hline $\begin{array}{l}\text { Inadequate } \\
\text { supervision } \\
(n=10)\end{array}$ & $\begin{array}{l}\text { Experiences of not receiving feed- } \\
\text { back when needed and not being } \\
\text { able to communicate frequently } \\
\text { enough. Inadequate supervision } \\
\text { was in many cases described as the } \\
\text { result of supervisors being too } \\
\text { busy with their work, stress or so- } \\
\text { cial-psychological problems as well } \\
\text { as substance abuse. }\end{array}$ & $\begin{array}{l}\text { I wasn't able to communicate } \\
\ldots \text { with my supervisor. I did- } \\
\text { n't see anyone interested in my } \\
\text { work, [I felt] alone. (86) }\end{array}$ & & \\
\hline $\begin{array}{l}\text { Supervisor } \\
\text { abandon- } \\
\text { ment }(n=3)\end{array}$ & $\begin{array}{l}\text { Experiences of supervisors leaving } \\
\text { the institution or even the country, } \\
\text { withdrawing themselves and leav- } \\
\text { ing the student to their own de- } \\
\text { vices. }\end{array}$ & $\begin{array}{l}\text { I asked my supervisor via e- } \\
\text { mail to sign my progress review } \\
\text { report and they replied that } \\
\text { they will no longer supervise } \\
\text { me (my timing was wrong - } \\
\text { they were at a conference and I } \\
\text { didn't know that). My super- } \\
\text { visor was very busy at that } \\
\text { time and I had just (three } \\
\text { weeks ago) had my third child } \\
\text { - I guess the emotions boiled } \\
\text { over for both of us. (68) }\end{array}$ & & \\
\hline
\end{tabular}




\begin{tabular}{|c|c|c|c|c|}
\hline $\begin{array}{l}\text { Themes } \\
\text { (no. of } \\
\text { events) }\end{array}$ & Description of the theme & Empirical examples & $\begin{array}{l}\text { Systemic } \\
\text { level }\end{array}$ & $\begin{array}{l}\text { Ethical } \\
\text { principle }\end{array}$ \\
\hline $\begin{array}{l}\text { Perceived un- } \\
\text { fairness of } \\
\text { the doctoral } \\
\text { progress re- } \\
\text { view process } \\
(\mathrm{n}=1)\end{array}$ & $\begin{array}{l}\text { Experiences and even reputed un- } \\
\text { fair treatment of students at pro- } \\
\text { gress review assessments in some } \\
\text { institutes, as the decisions of the } \\
\text { faculty are influenced by financial } \\
\text { pressures. }\end{array}$ & $\begin{array}{l}\text { The doctoral progress review at } \\
\text { the [institute] was never a very } \\
\text { fair process. I felt relieved ... } \\
\text { but [also] that injustice was } \\
\text { done to other doctoral students } \\
\text { as the institute wishes to cut } \\
\text { down on expenses. (6) }\end{array}$ & \multirow{3}{*}{ Structural } & \multirow{3}{*}{ 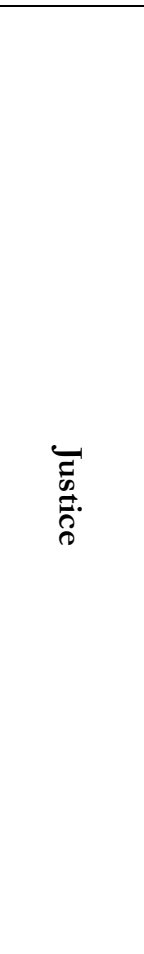 } \\
\hline $\begin{array}{l}\text { Discriminat- } \\
\text { ing power hi- } \\
\text { erarchies in } \\
\text { academia } \\
\text { when solving } \\
\text { conflict situ- } \\
\text { ations }(n=3)\end{array}$ & $\begin{array}{l}\text { Experiences of uneven power rela- } \\
\text { tionships in instances of conflict } \\
\text { resolution, the all-around defense } \\
\text { of the faculty when solving prob- } \\
\text { lems, feelings of being sacrificed by } \\
\text { the academic community for the } \\
\text { benefit of those in more powerful } \\
\text { positions. Perceived inequitable re- } \\
\text { sponsibility for the effectiveness of } \\
\text { the doctorate. }\end{array}$ & $\begin{array}{l}\text { In my experience, it's impossi- } \\
\text { ble to change the situation from } \\
\text { the inside out, as the manage- } \\
\text { ments of the institutes form a } \\
\text { so-called all-around defense by } \\
\text { supervisors and, in many cases, } \\
\text { there can be complicity or they } \\
\text { can be derogated by analogical } \\
\text { cases. (36) }\end{array}$ & & \\
\hline $\begin{array}{l}\text { Favoritism } \\
(\mathrm{n}=1)\end{array}$ & $\begin{array}{l}\text { Promises for developmental possi- } \\
\text { bilities are made based on collegial } \\
\text { relationships. }\end{array}$ & $\begin{array}{l}\text { I didn't get admitted to the } \\
\text { PhD program in my institute, } \\
\text { although everybody had con- } \\
\text { firmed that I would get in, no } \\
\text { doubt. (48) }\end{array}$ & & \\
\hline $\begin{array}{l}\text { Exploitation } \\
(\mathrm{n}=4)\end{array}$ & $\begin{array}{l}\text { Situations where the supervisors } \\
\text { strongly ask or encourage students } \\
\text { to do something, although the re- } \\
\text { sults may be not beneficial to the } \\
\text { student or the student may feel un- } \\
\text { comfortable and have no courage } \\
\text { to refuse. This theme includes dual } \\
\text { relationships - cases where there is } \\
\text { lack of transparency of the rela- } \\
\text { tionships among research group } \\
\text { members - and unclear and unfair } \\
\text { assignment of credit for contribu- } \\
\text { tion to the project. }\end{array}$ & $\begin{array}{l}\text { My supervisor asked me to re- } \\
\text { view their article. It was very } \\
\text { uncomfortable and I felt cor- } \\
\text { nered. (1) }\end{array}$ & Individual & \multirow{2}{*}{$\begin{array}{l}Z \\
\text { Z } \\
0 \\
1 \\
3 \\
0 \\
0 \\
0 \\
0 \\
0 \\
0 \\
0 \\
0\end{array}$} \\
\hline $\begin{array}{l}\text { Detrimental } \\
\text { atmosphere } \\
\text { at the pro- } \\
\text { gress review } \\
\text { assessment } \\
(\mathrm{n}=4)\end{array}$ & $\begin{array}{l}\text { The progress review assessment } \\
\text { was experienced as psychologically } \\
\text { harmful in some cases. Students re- } \\
\text { ported unprofessional behavior of } \\
\text { individual progress review commit- } \\
\text { tee members and also reported } \\
\text { leaving the assessment feeling defi- } \\
\text { cient, misprized and belittled. }\end{array}$ & $\begin{array}{l}\text {... lack of any support, un- } \\
\text { professional treatment. (61) }\end{array}$ & Structural & \\
\hline
\end{tabular}




\begin{tabular}{|c|c|c|c|c|}
\hline $\begin{array}{l}\text { Themes } \\
\text { (no. of } \\
\text { events) }\end{array}$ & Description of the theme & Empirical examples & $\begin{array}{l}\text { Systemic } \\
\text { level }\end{array}$ & $\begin{array}{l}\text { Ethical } \\
\text { principle }\end{array}$ \\
\hline $\begin{array}{l}\text { Exploitation } \\
(\mathrm{n}=1)\end{array}$ & $\begin{array}{l}\text { A salaried doctoral student was } \\
\text { asked to write a resignation letter } \\
\text { because paying a stipend was finan- } \\
\text { cially more advantageous for the } \\
\text { department than paying a salary. } \\
\text { The student however lost out on } \\
\text { social benefits because student al- } \\
\text { lowance is not taxable nor does it } \\
\text { require social security payments } \\
\text { from the department. }\end{array}$ & $\begin{array}{l}\text { I was asked to write a resigna- } \\
\text { tion letter because paying me a } \\
\text { stipend is financially more ad- } \\
\text { vantageous for the department. } \\
\text { Being employed means having } \\
\text { some social guarantees which } \\
\text { the stipend doesn't secure. The } \\
\text { status of an employee is wor- } \\
\text { thier than the status of a stu- } \\
\text { dent. [I feel] that the univer- } \\
\text { sity is extremely hypocritical } \\
\text { regarding the whole doctorate. } \\
\text { (32) }\end{array}$ & & \\
\hline $\begin{array}{l}\text { Peer compe- } \\
\text { tition for } \\
\text { funding op- } \\
\text { portunities } \\
(\mathrm{n}=1)\end{array}$ & $\begin{array}{l}\text { Detrimental competition at the ex- } \\
\text { pense of collaboration }\end{array}$ & $\begin{array}{l}\text { My fellow doctoral student (I } \\
\text { considered them a good friend) } \\
\text { and I both wanted to attend } \\
\text { the same conference and were } \\
\text { looking for financing opportu- } \\
\text { nities. It turned out that my } \\
\text { friend didn't tell me about a } \\
\text { few opportunities because they } \\
\text { were afraid I was going to ap- } \\
\text { ply for them too and therefore } \\
\text { they may not get the financing. } \\
\text { Until then I hadn't considered } \\
\text { us as competitors. (63) }\end{array}$ & & \\
\hline Total $=59$ & & & & \\
\hline
\end{tabular}

\section{RESULTS}

In the following, we present the results according to the five common ethical principles breached in the themes and associated with doctoral studies' systemic levels we found the challenges located in. The selected quotations for illustrating the study results were translated into English when they were initially provided in Estonian.

\section{AUTONOMY}

\section{Intolerance for differing opinions}

The principle of autonomy was at risk on the individual level of studies, with issues related to intolerance for differing opinions. The participants felt that they could not develop their own ideas in their research and perceived some discussions with supervisors on the content or the research process's planning as intrusive. Additionally, participants described having to avoid criticizing or opposing the views of their supervisors. A different viewpoint may have led to rejection, as one student suggested, "My supervisor neglected me after I wrote a critical review about the work of one of [their] protégées” (87). 


\section{Faculty members critique of students' independent choices}

Similar experiences were identified at the structural level of studies at the yearly progress review assessments, where committee members criticized students for independently made choices in research. Students described leaving the assessment feeling confused and disappointed. One student described their experience as follows:

A conference presentation was crossed off at the progress review assessment. ... [I felt] frustrated (why had nobody told me to pay attention to it [that this could be irrelevant]), depressed (because of the time wasted), embarrassed (because I had presented it for the assessment) and confused (about how to go on). (75)

It seems that the student was held responsible for something that could have easily been avoided by the provision of the necessary information and timely guidance by a supervisor or the faculty. The quotation suggests that apparently, the supervisor did not interfere, nor did they consult the conference's choice. Making adequate choices requires some competence, which doctoral students as less experienced academics may not always have. The decisions need to be informed, and in this case, the support of the supervisor and the faculty was clearly needed. Both a lack of autonomy as well as too much independence can have negative consequences for the student. However, in this experience, the negative consequences at the progress review assessment took the form of being condemned by the faculty for too much independence, and resulted in the loss of valuable credit points and negative emotions about the process.

\section{BENEFICENCE}

Lack of support from the academic community, lack of financial support, and bureaucratic documentation compromised the principle of beneficence at the structural level of the doctoral experience.

\section{Lack of support from the academic community}

Doctoral students reported situations when the faculty failed to support and contribute to their welfare, failing to respond to students' struggles with research, lack of progress in studies, or lack of sufficient supervision. In these cases, the active engagement of the surrounding academic community was needed. Some of the students described isolation and loneliness in the research process: "I think the most negative side of doctoral studies is that while research is supposed to be collective, you are still alone when writing your dissertation or solving problems" (35). At the same time, others missed social support from the academic community in a broader sense. One student described it as "[the] growing feeling and experience of alienation; not feeling part of the collective, of the institute; having no friends" (82).

\section{Lack of financial support}

Lack of financial support was another challenge that doctoral students experienced during their studies. To overcome financial uncertainty, students reported the need to find additional income, which meant being employed outside the university and having less time for their research and studies. Modest stipends and low financial income for research left them feeling that their work in research was not valued:

This is how much the government appreciates scientists, do your best for 422 euros a month and then go and tell the world how good and outstanding we are for your own money. I'll say it straight out. My other jobs are funding my $\mathrm{PhD}$ studies anyway, and I will not pay for representing my university and my country out of my pocket! (52)

This quotation indicates that the student expected reciprocal appreciation from the state and their institution for their input, which seemed to be lacking despite student's efforts to live up to what they 
perceived as institutional and governmental expectations. How doctoral students described their financial struggles associated with structural level challenges, often alluding to a feeling of being treated unfairly, even exploited, without proper compensation.

\section{Bureaucratic documentation}

Bureaucratic documentation was reported as one of the challenging experiences. Doctoral students found the bureaucracy involved when reporting on their progress or applying for a scholarship or a stipend (e.g., to attend an international conference or study abroad) excessively time-consuming and complicated. For example, one of the students expressed the impression that reporting was detached from its content and purpose: "You have to report on your progress or deal with financial issues. Reporting of any kind seems to be pure bureaucracy, no one cares much about the content, but you have to do it, often duplicated" (9). These experiences were described as unreasonable and contradictory to the inherent values of academic growth and impeded necessary development opportunities. In these cases, the system failed to benefit doctoral students, as the student quoted above concluded, "it feels as if they don't want doctoral students to be able to socialize with international colleagues" (9). This doctoral student has been left with an experience of mixed messages and perhaps a hidden agenda to figure out.

\section{Disregarding students' wellbeing}

At the intersection of the individual and structural level, we found disregarding students' wellbeing to be an ethically challenging theme. The students described dealing with burnout and exhaustion: "[I guess] I was heading straight to burnout. ... I realized that doctoral studies cannot be more important than my health. ... I felt sad (periodically I counted the days when I was not crying), resigned, enormously tired, overloaded" (59).

\section{FIDELITY}

The principle of fidelity was at risk at the individual level of doctoral studies in student-related aspects and as challenges in the supervisory relationship.

\section{Students' struggle to keep study-related promises}

Student-related aspects included struggles to keep study-related promises and meet the expectations of the doctoral program, supervisors, and oneself. Having a full-time job could lead to a lack of time for studies and difficulties in keeping study-related commitments, as illustrated by the following quotation:

I didn't have enough time for my doctoral studies due to the workload [outside the university]. At the beginning of my studies, I was very motivated to work on my dissertation, but the motivation faded with tiredness and lack of time. (15)

Fading motivation when having an interesting and fulfilling job outside the university was described in doctoral students' vignettes. This, combined with having little or no support from the academic community, could lead students to lay aside their studies. Looking back on the critical experience of losing motivation for their doctoral studies due to a new and exciting job opportunity outside the university, one of the students wrote: "However, I can't see how I could have acted differently under the same circumstances (without a support group and having a full-time job)" (24). Still, experiencing feelings of guilt and shame, having a bad conscience, and being disappointed in themselves were present in these vignettes. The need to balance work and doctoral studies was described as burdensome, as one student explained, "because in my opinion I was not doing enough for the university nor for my job. I felt ... enormously tired, overloaded" (59).

It seems that in the above described moments, the circumstances hindered the students from fulfilling their commitments. Nevertheless, when applying and enrolling for doctoral studies, the student 
could reasonably be expected to make a sincere effort to conduct research and fulfill other study requirements. In return, the student could expect the university to offer opportunities to study courses to fulfill requirements and receive supervision to conduct and complete research work. Either party may have been fallen short of fulfilling the other party's expectations and, in this way, may not have been able to deliver what regarded as the duty of that party. While it is understandable that students' life circumstances may change during their studies, the crucial aspect appeared to be how these were communicated between the student and the supervisor and whether there were mechanisms in place for study exit, which could allow all parties to maintain dignity.

Other challenges to the principle of fidelity were located in the supervisory relationship, namely inadequate supervision and supervisor abandonment.

\section{Inadequate supervision}

Doctoral students described experiences of not receiving feedback when needed and not being able to communicate with their supervisors frequently enough. While students may have had different expectations of what is considered proper frequency, the common perception was failed supervision. One participant reported: "I basically lost contact with my main supervisor, this strongly affected my motivation and the way I look at academic life as a whole. I felt that doctoral studies are pointless" (22). This quotation shows that other than losing motivation, inadequate supervision may have led the student to question the studies' meaningfulness. Inadequate supervision was reported as the result of supervisors being too busy with their work. For example, a doctoral student reported that their supervisor was occupied with their own writing project, leaving no time to engage in supervising the student. Doctoral students also perceived their supervisors to have stress or social-psychological problems, as well as substance abuse, which led to insufficient communication and inadequate supervision. While there may have been a myriad of reasons for failure to supervise, the critical aspect here was that the students interpreted supervision to be of low priority for the supervisors, failing to live up to a promise.

\section{Supervisor abandonment}

Supervisor abandonment manifested in experiences, when, for instance, supervisors left either the country or the institution, or both, leaving their students to their own devices. The vignettes showed that these situations were unexpected for doctoral students and led to confusion and unawareness of the future. One of the doctoral students expressed their feelings: "I felt like this is over, I cannot defend" (20). Another doctoral student tried to reason the withdrawal of the supervisor:

my timing was wrong - they were at a conference, and I didn't know that. My supervisor was very busy at that time, and I had just (three weeks ago) had my third child - I guess the emotions boiled over for the both of us. (68)

This quote illustrates care and concern about the circumstances of the supervisory bond from the student's perspective. The situation emphasizes the responsibility of the academic community when the supervisory relationship must be terminated or mediated.

\section{JUSTICE}

The principle of justice was compromised at the structural level in doctoral students' experiences.

\section{Perceived unfairness of the doctoral progress review process}

Justice-related challenges were experienced as perceived unfairness of the doctoral progress review process. A participant who had received a favorable review at the assessment questioned the fairness of the treatment of other students in this process, and they suspected that parameters outside perfor- 
mance influenced feedback and review decisions in the annual progress review: "The doctoral progress review assessment at the [institute] was never a very fair process. I felt relieved ... but [also] that injustice was done to other doctoral students as the institute wishes to cut down on expenses" (6).

The progress review puts pressure on students, which may motivate students in a positive way. However, examples were given where the progress review was the single most negative experience influencing doctoral studies. Therefore, it is evident that, for the students, the experiences were not constructive and injustice dominated.

\section{Discriminating power hierarchies in academia when resolving conflict situations}

Next, doctoral students reported discriminating power hierarchies in academia when resolving conflict situations. For example, one doctoral student voiced concerns over what they interpreted as the sacrifice of a few individuals with little power for the benefit of those in a more powerful position:

Despite the official regulations implemented by the university, the interpretation of the ethics of supervisors' acts, conflicts of interest, and responsibilities is carried out based on the needs of the situation. ... The damage caused by punishing a supervisor is considered significantly higher than that caused by destroying the research careers of a few doctoral students.

Situations, where the solutions to complicated matters were favorable for parties higher up in the academic hierarchy had, according to the vignettes, a negative impact on doctoral students' experiences.

\section{Favoritism}

Another form of ethically challenging experience concerned favoritism. A student reported their disappointment when they did not get admitted to the $\mathrm{PhD}$ program at their institute, although faculty had previously ensured they would be accepted. There was a structural problem, as the student had been promised a place in the doctoral program before the admission process.

\section{NON-MALEFICENCE}

\section{Exploitation}

At the individual systemic level, doctoral students described exploitation experiences, including dual relationships and unclear assignment of authorship in the supervisory relationship.

Doctoral students described situations where supervisors strongly asked or encouraged students to do something, not recognizing that the outcomes may not benefit them. Doctoral students found it hard to refuse their supervisors' requests and, as a consequence, found themselves in distressed and uncomfortable situations. For instance, one of the students reported issues related to workload:

I had to write the last article for my dissertation, being still on parental leave (although I still had two years of studies ahead of me) practically without any financial support. It's now difficult for me to earn money back with additional employment, as my supervisors have given me new assignments that are not required for my doctoral dissertation. This causes a needless amount of additional workload alongside raising a toddler and compounds my financial situation. I still feel bitter and irritated for being treated as an unpaid workforce. (27)

The supervisors may have acted unintentionally without understanding the student's life situation and study requirements; however, the quotation illustrates that the doctoral student experience was characterized by exploitation.

Exploitation also took the form of dual relationships, which affected doctoral students working in the same research group. As one doctoral student declared: "It turned out that my supervisor had an 
intimate relationship with one of my fellow students for years ... they regarded the other doctoral students as a cheap and simple-minded workforce" (36). This comment concerns the experience of betrayal when there is a lack of transparency among research group members. Retrospectively, individuals may interpret past events as power intrigues irrespective of whether or not this has been the case. It is important to recognize that people have a right to privacy, and this is an ethical matter as well. While part of that privacy may be the choice to not disclose the nature of a relationship between two adults, it is important to recognize the consequences of non-disclosure as well. The doctoral student, who is often the party with less formal power, is more vulnerable in such a relationship, and this is generally the primary concern. In this case, a bystander was affected by the relationship, and the derogatory language made the individual even more vulnerable to the power differential.

At the individual level, the question of authorship arose. One of the participants voiced the experience of students' ideas being exploited without credit:

My supervisor omitted me as a co-author in one article, although I thought I could publish this article with them. I had participated in generating the idea and had the impression that this was going to be a part of my doctoral thesis. As it turned out, it wasn't. I lost trust in my supervisor and felt betrayed. (39)

Authorship is among the most important ways for young scholars to merit themselves, not least if they are writing an article-based dissertation. Based on the information in the quotation, we do not know whether or not the doctoral student actually contributed in a way that would warrant authorship. However, the quotation illustrates that the principles for assigning authorship may not always be clear, and practices may not always be ethically sustainable. What is clear from the quote is that in this case, the supervisor and their student did not discuss the right to be an author, leaving the doctoral student feeling betrayed and with a supervision relationship that would most likely be difficult to mend.

\section{Detrimental atmosphere at the progress review assessment}

We found the principle of 'doing no harm' at the structural level of doctoral studies to be at risk in experiences of a detrimental atmosphere at the progress review assessment. Psychologically harmful experiences of the progress review assessment were suggested in the vignettes. Doctoral students reported the unprofessional behavior of the assessment committee members. One of the students recalled:

I knew I had worked hard, but after the comments of the progress review committee, I felt that everything I had done was wrong and that my topic was unworthy of study. ... I felt sad, incapable, and like a failure. (30)

The principle of non-maleficence could be breached if the student experience verged of bullying or psychological harm, with negative effects on self-esteem and self-efficacy. We found a pattern of students leaving the assessment feeling deficient, unappreciated, and belittled, implying a failure on behalf of committee members to avoid harm, as their practice may have caused more harm to than promotion of development.

\section{Exploitation}

The principle of non-maleficence was at risk at the structural level of doctoral studies in the form of exploitation. One of the salaried doctoral students experienced a situation where the faculty asked them to write a resignation letter because paying a stipend was financially more advantageous for the department than salary. However, as a consequence, the student lost out on social benefits because "Being employed means having some social guarantees which the stipend doesn't secure" (32). Again, the student had no power to decline the faculty's request, and the faculty did not consider the student's financial and social consequences. 


\section{Peer competition for funding opportunities}

We found the theme of peer competition for funding opportunities to be a structural level ethical challenge breaching the principle of non-maleficence. In one case, limited opportunity for financing attendance at an international conference led to detrimental competition between doctoral students at the expense of collaboration. Avoiding the development of a negatively competitive climate at the structural level of studies would be in line with the principle of non-maleficence. Here, applying for limited resources led peers to withhold useful information and compete as the doctoral student concluded: "Until then I hadn't considered us competitors" (63).

\section{DISCUSSION}

This study set out to identify the ethical nature of the challenges doctoral students experience during their studies. Whereas prior research has identified ethical issues in the context of supervisory relationships (Brown \& Krager, 1985; Goodyear et al., 1992; Löfström \& Pyhältö, 2012, 2014, 2015; Rosenberg \& Heimberg, 2009), our study pointed to ethical challenges at the varied systemic levels of doctoral studies. We consider this important, as ethical challenges are best solved when addressed at the appropriate level, i.e., where they emerge.

Based on the results, we have identified both individual and structural level ethical challenges. The latter dominated breaches of the ethical principles in doctoral students' experiences of doctoral studies. Structural problems have been identified as the main concern in Estonian doctoral education before (Vassil \& Solvak, 2012), which implies the persistent nature of these challenges despite numerous efforts to develop educational and institutional policies.

At the individual level of doctoral studies, ethical challenges emerged in supervisory relationships and association with student-related aspects. Ethical challenges pertaining to breaches of fidelity in the supervisory relationship involved supervision abandonment and inadequate supervision. The principle of fidelity refers to trust in an interpersonal relationship built over time by keeping promises and being truthful. As novice academics, doctoral students entrust themselves to their supervisors, who must assure consistent support and guidance throughout the process, empowering and "giving students an optimal opportunity to succeed" (Brown \& Krager, 1985, p. 408). The results showed that trust was broken through abandonment and lack of support. Supervision did not always match the frequency and quality expected by doctoral students. Similar issues have been identified as ethically challenging in prior research on doctoral students' experiences (Goodyear et al., 1992; Löfström \& Pyhältö, 2017). The supervisory relationship is influential, as dissatisfaction with supervision can lead to burnout and attrition intentions (Cornér et al., 2017). To develop a trusting relationship, openness and honesty are required, where both parties clearly voice their expectations and beliefs about doctoral studies and supervision. Nevertheless, the supervisory relationship is often based on implicit agreement, and this seems to be the root cause for potential challenges, as supervisors and doctoral students have different expectations (Golde, 2005; Löfström \& Pyhältö, 2015). Doctoral students observed their supervisors' heavy workloads, stress, and even substance abuse as causes of inadequate supervision. This, in turn, made the students question their futures as academics. Indeed, supervisors are balancing different roles and responsibilities in academia (Löfström \& Pyhältö, 2015), and there is evidence of doctoral students witnessing faculty life as out of balance, leading them to avoid an academic career (Golde, 2005).

On the other side of fidelity, participants described their struggles in keeping study-related commitments or maintaining their motivation. Students' personal characteristics, such as motivation and selfregulative skills, are known to be important for doctoral studies (Bair \& Haworth, 2004; Pyhältö et al., 2012b). In this study, participants struggled with commitment and motivation due to work responsibilities outside the university. The ongoing balancing act between doctoral studies and other responsibilities may lead to stress and, consequently, to attrition (Bair \& Haworth, 2004; Pyhältö et al., 2012b). Without paid work outside the university, doctoral students could not cope financially and, as a result, experienced exhaustion and burnout as well as guilt and shame for not keeping their 
Ethical Perspective on Challenges in Doctoral Education

study commitment. Considering the context, the current findings are quite remarkable, revealing that doctoral students take responsibility for their studies and deeply consider their personal input even though the challenges they face originate from the structural organization of doctoral studies. Therefore, although a trusting supervisory relationship was experienced as being threatened by both students and supervisors and made itself visible at the individual level of doctoral studies, the issue seems to be grounded in the structural level of doctoral studies in both cases.

The results indicate that the principle of avoiding harm is at risk in supervisory relationships. In line with previous research findings, participants wrote of exploitation, including non-transparent and unfair practices concerning the assignment of authorship and dual relationships. Exploitation in the form of overly high workloads is an issue that has concerned both students and supervisors (Löfström \& Pyhältö, 2017), but dual relationships have rather challenged supervisors (Löfström \& Pyhältö, 2012, 2017). Our data showed that bystanders to dual relationships described the experience as harmful because the relationship affected a broader pool of individuals than just the primary parties involved. Concerning non-maleficence, this study aligns with prior studies (Löfström \& Pyhältö, 2014) in reporting authorship issues. Institutions have a great responsibility to make sure that common guidelines are in place to identify the contributions considered prerequisites for authorship and the types of unacceptable practices. Although many institutions have codes of conduct for research, where authorship questions are commonly addressed, an explicit agreement between parties may help set out the premises of cooperation and sustain a functional supervisory relationship.

Previous research has indicated that the lack of autonomy in doctoral studies may hinder students from developing an independent researcher identity (Johnson et al., 2010; Löfström \& Pyhältö, 2015). Similarly, not all doctoral students in this study felt that they could develop their own research ideas and sensed that having opposing viewpoints to supervisors was unacceptable to the latter. These findings are consistent with those of Löfström and Pyhältö (2014, 2017), who described students' efforts in finding their own selves as researchers. This seems to be one of the ethical focal points in the supervisory relationship, as supervisors may be insecure about whether and how strongly to insist on their viewpoints (Löfström \& Pyhältö, 2012). Nevertheless, supporting students' autonomous thinking and activities as researchers may not lead to greater satisfaction with supervision, but it contributes to greater research self-efficacy (Overall et al., 2011).

The commonly reported challenges in doctoral students' experiences at the structural level of their studies were the academic community's lack of support, the lack of financial support, bureaucratic documentation, and hierarchical power considerations when resolving conflicts. Adding an ethical perspective to these experiences shows the principles of beneficence and justice to be at risk. Breaches of beneficence took the form of a lack of support from the academic community, loneliness, and isolation in the research process and the community. Research has emphasized the crucial role of academic community support in successful doctoral studies (Corcelles et al., 2019; Pyhältö et al., 2012a; Peltonen et al., 2017; Sala-Bubaré \& Castelló, 2017). The results of our study imply that, while the faculty may still consider supporting the development of doctoral students to be mainly the supervisors' responsibility, input and interventions from community members are needed when students struggle with their studies or encounter a lack of adequate supervision, as noted in prior research (Leijen et al., 2016). In addition, breaches of justice took the form of discriminating power hierarchies when resolving conflicts and feelings of being sacrificed by the academic community to benefit those in more powerful positions. Hierarchical considerations impede the fair treatment of parties.

Lack of financial support and bureaucratic documentation were doctoral students' experiences that we considered breaches of the principle of beneficence at the structural level of doctoral studies. The provision of incentives for full-time engagement is considered a precondition for successful doctoral studies (Corcelles et al., 2019; Vassil \& Solvak, 2012). Low income for research left doctoral students feeling worthless. When undertaking doctoral studies, they felt that they committed them- 
selves to the institution and their studies, trying to live up to what they perceived to be the institution's expectations. According to students, reasonable compensation would signal reciprocal commitment on the part of the institution or the state. Students also felt that it is the institution's responsibility to support them by simplifying procedures, such as progress review documentation and scholarship or stipend application. Time-consuming and complicated bureaucracy was perceived as contradictory to the inherent values of supporting academic growth. Therefore, ethical considerations could be integrated when creating and implementing rules and policies: are these rather obstructive, or do they allow institutions and departments to act in line with the aim of creating a supportive environment for doctoral students?

Another significant aspect concerning ethically challenging experiences, according to our study, was the yearly progress review assessment. Eamets et al. (2014) suggested the standardization of the doctoral progress review's regulations and requirements, as the implementation and results vary among study fields, and the expectations of parties towards the process differ. Our study implies that the progress review assessment compromises the principles of avoiding harm, being just, and having respect for others' autonomy. The participants described leaving the assessment feeling as though they had been treated unprofessionally, belittled, treated unfairly, and criticized for their choices in research. Our findings are in line with previous research, which suggested that the progress review is experienced as formal (Eamets et al., 2014), unsupportive (Leijen et al., 2016), and a rather administrative procedure lacking pedagogical value (Mewburn et al., 2014). The aim of the progress review should not be to promote the culture of hard criticism. Instead, its intentions should be to support and assist students, as suggested by Leijen et al. (2016). A supportive atmosphere in the research community is a powerful resource in doctoral studies (Pyhältö et al., 2012a). Although the progress review is widely used as an efficiency measure in Europe and elsewhere for keeping track of doctoral students' progress and providing feedback, especially on systems in which performance-based funding is implemented, there is rather little research on the culture of progress reporting (Mewburn et al., 2014). The present study highlights that progress reporting and assessment might be ethically challenging, as the process involves the use of power. We, therefore, propose the ethical aspects in the progress assessment process as a theme for further investigation.

Based on our results, the ethical challenges doctoral students face during their studies are multidimensional and need to be solved on many levels. Although several issues presented themselves in the supervisory relationship, a number seemed to be rooted in the broader academic community. We identified the majority of breaches to be located at the structural level of doctoral studies. Our results further support the idea of Halse and Bansel (2012), who argued that seeing supervisors exclusively responsible for doctoral students is a limitation to the conceptualization of doctoral supervision and also quite an unequal distribution of responsibility for a successful doctorate.

\section{LIMITATIONS}

There are limitations in this research. First, the ethical challenges were identified based on the researchers' interpretations. Had we asked the participants directly about the ethical challenges, other challenges, and more extreme cases may have emerged. Löfström and Pyhältö (2012, 2014, 2015, 2017) also identified ethical issues in descriptions of doctoral studies and supervision as latent themes (cf. Braun \& Clarke, 2006) in interviews. Their studies showed that ethical issues are typically non-dramatic and rather ordinary experiences of having not being treated the 'right way'. Nevertheless, using open-ended prompts on significant negative experiences, it was possible to identify a wide range of experiences from the rather ordinary to the more extreme and identify whether negative experiences tend to be associated with ethical challenges. This study demonstrated that, of the negative experiences, many indeed do have ethically problematic aspects.

Secondly, the data collection method set some limitations on the elaboration and depth of the data. While we did gather responses from relatively many doctoral students, we propose exploring some of 
the raised themes, e.g., experiences around the ethics in the progress review process, through interviews.

Last, the study presented single-institution data. While this is common in qualitative educational studies, it is necessary to recognize that some of the results may reflect underlying local cultural practices rather than general manifestations of ethics. However, the five ethical principles provide a fairly robust lens for ethics, and these have been identified as commonly accepted principles in academia, as is evident from their presence in various codes of conduct in research. Furthermore, the principles have been identified in doctoral education in other cultural contexts (cf. Löfström \& Pyhältö, 2012, 2014, 2015, 2017, 2020). Emphases, however, may be contextual. For instance, we recognize that not all countries or institutions apply progress reporting, and, consequently, the reports on this issue may not emerge among issues of justice in other contexts. The same applies to interpretations of monthly compensation. Even a small monthly compensation might be viewed differently in a context where there are only competitive grants. In the context of this study, some participants considered the compensation unfair and an indication of a low appreciation for doctoral students' work.

\section{CONCLUSION}

The current study contributes to understanding doctoral students' perceptions of the systemic challenges emerging during their doctoral studies from an ethical perspective. The study identified potential and sometimes subtle sources of challenges that may go unrecognized until they become problems that hinder studies' progression. McAlpine et al. (2012) emphasized the student-institution dichotomy, in which structural issues may be attributed to doctoral students. The current study unveiled some individual-level issues to be associated with structural level matters. In accordance with previous research, which indicated the importance of the thorough support of doctoral students at the institutional level (Corcelles et al., 2019; Halse \& Bansel, 2012; McAlpine, 2013), our research results highlight the need for joint responsibility by the academic community for successful doctoral studies. We suggest that more effective means supporting the doctoral graduate process can be developed when considering the ethical aspects of mutual relationships and responsibilities among students, supervisors, and the university.

\section{ACKNOWLEDGMENTS}

We want to thank the doctoral students who participated in the research for sharing their experiences with us. We also thank the anonymous reviewers for their valuable feedback on earlier versions of this article.

\section{REFERENCES}

Alfredo, K., \& Hart, H. (2011). The university and the responsible conduct of research: Who is responsible for what? Science and Engineering Ethics, 17, 447-457. https://doi.org/10.1007/s11948-010-9217-3

Anderson, M. S., \& Louis, K. S. (1994). The graduate student experience and subscription to the norms of science. Research in Higher Education, 35(3), 273-299. https://doi.org/10.1007/BF02496825

Bair, C. R., \& Haworth, J. G. (2004). Doctoral student attrition and persistence: A meta-synthesis of research. In J. C. Smart. (Ed.), Higher education: Handbook of theory and research (pp. 481-534). Springer. https://doi.org/10.1007/1-4020-2456-8 11

Braun, V., \& Clarke, V. (2006). Using thematic analysis in psychology. Qualitative Research in Psychology, 3(2), $77-$ 101. https://doi.org/10.1191/1478088706qp063oa

Braun, V., \& Clarke, V. (2016). (Mis)conceptualising themes, thematic analysis, and other problems with Fugard and Potts' (2015) sample-size tool for thematic analysis. International Journal of Social Research Methodology, 19(6), 739-743. https://doi.org/10.1080/13645579.2016.1195588

Braun, V., \& Clarke, V. (2019). Reflecting on reflexive thematic analysis. Qualitative Research in Sport, Exercise and Health, 11(4), 589-597. https://doi.org/10.1080/2159676X.2019.1628806 
Braun, V., \& Clarke, V. (2020). One size fits all? What counts as quality practice in (reflexive) thematic analysis? Qualitative Research in Psychology, 1(25). https://doi.org/10.1080/14780887.2020.1769238

Braun, V., Clarke, V., \& Weate, P. (2016). Using thematic analysis in sport and exercise research. In B. Smith \& A. Sparkes (Eds.), Routledge bandbook of qualitative research methods in sport and exercise (pp. 191-205). Routledge.

Brown, R. D., \& Krager, L. (1985). Ethical issues in graduate education: Faculty and student responsibilities. The Journal of Higher Education, 56(4), 403-418. https://doi.org/10.2307/1981303

Castelló, M., Pardo, M., Sala-Bubaré, A., \& Suñe-Soler, N. (2017). Why do students consider dropping out of doctoral degrees? Institutional and personal factors. The International Journal of Higher Education Research, 74(6), 1053-1068. https://doi.org/10.1007/s10734-016-0106-9

Cornér, S. (2020). The socially-embedded support system in doctoral education [Doctoral dissertation, University of Helsinki]. https://helda.helsinki.fi/handle/10138/311664

Cornér, S., Löfström, E., \& Pyhältö, K. (2017). The relationship between doctoral students' perceptions of supervision and burnout. International Journal of Doctoral Studies, 12, 91-106. https://doi.org/10.28945/3754

Cornér, S., Pyhältö, K., \& Löfström, E. (2019). Supervisors' perceptions of primary resources and challenges of the doctoral journey. International Journal of Teaching and Learning in Higher Education, 31(3), 365-377.

Cornér, S., Pyhältö, K., Peltonen, J., \& Bengtsen, S. S. E. (2018). Similar or different? Researcher community and supervisory support experiences among Danish and Finnish social sciences and humanities $\mathrm{PhD}$ students. Studies in Graduate and Postgraduate Education, 9(2), 274-295. https://doi.org/10.1108/SGPE-D-18$\underline{00003}$

Cornwall, J., Mayland, E. C., van der Meer, J., Spronken-Smith, R. A., Tustin, C., \& Blyth, P. (2019). Stressors in early-stage doctoral students. Studies in Continuing Education, 41(3), 363-380. https://doi.org/10.1080/0158037X.2018.1534821

Corcelles, M., Cano, M., Liesa, E., Gonzáles-Ocampo, G., \& Castelló, M. (2019). Positive and negative experiences related to doctoral study conditions. Higher Education Research and Development, 38(5), 922-939. https://doi.org/10.1080/07294360.2019.1602596

Couch, S., \& Dodd, S. (2005). Doing the right thing: Ethical issues in higher education. Journal of Family and Consumer Sciences, 97(3), 20.

Cumming, J. (2010). Doctoral enterprise: A holistic conception of evolving practices and arrangements. Studies in Higher Education, 35(1), 25-39. https://doi.org/10.1080/03075070902825899

De Clercq, M., Devos, C., Frenay, M., Klein, O., \& Galand, B. (2019). I need somebody to lean on: The effect of peer, relative, and supervisor support on emotions, perceived progress, and persistence in different stages of doctoral advancement. Swiss Journal of Psychology, 78, 101-113. https://doi.org/10.1024/1421$\underline{0185 / \mathrm{a} 000224}$

Eamets, R., Tamm, K., Tamm-Klaos, D., Aksen, M., Kärner, A., \& Kindsiko, E. (2014). Doktoriōppe tulemuslikekuse analüis. Uuringu 2.4. löppraport. (Analysis of the efficiency of the PhD studies). http://dspace.ut.ee/bitstream/handle/10062/40958/TIPS doktorioppe tulemuslikkuse loppraport.pdf

European Federation of Academies of Sciences and Humanities. (2017). European code of conduct for research integrity. https://allea.org/code-of-conduct/

Golde, C. M. (2005). The role of the department and discipline in doctoral student attrition: Lessons from four departments. The Journal of Higher Education, 76(6), 669-700. https://doi.org/10.1080/00221546.2005.11772304

Goodyear, R. K., Crego, C. A., \& Johnston, M. W. (1992). Ethical issues in the supervision of student research: A study of critical incidents. Professional Psychology: Research and Practice, 23, 203-210. https://doi.org/10.1037/0735-7028.23.3.203

Gray, P. W., \& Jordan, S. R. (2012). Supervisors and academic integrity: Supervisors as exemplars and mentors. Journal of Academic Ethics, 10(4), 299-311. https://doi.org/10.1007/s10805-012-9155-6

Halse, C., \& Bansel, P. (2012). The learning alliance: Ethics in doctoral supervision. Oxford Review of Education, 38(4), 377-392. https://doi.org/10.1080/03054985.2012.706219 
Ethical Perspective on Challenges in Doctoral Education

Hlebec, V., Kogovšek, T., \& Ferligoj, A. (2011). The influence of social support and personal networks on doctoral student performance. Metodoloskki zvękei, 8(2), 157-171.

Holzweiss, P., \& Walker, D. (2016). Ethics in higher education: Using collective experiences to enhance new professional training. Journal of Student Affairs Research and Practice, 53(4), 429-443. https://doi.org/10.1080/19496591.2016.1202836

Jairam, D., \& Kahl, D. H., Jr. (2012). Navigating the doctoral experience: The role of social support in successful degree completion. International Journal of Doctoral Studies, 7, 311-329. https://doi.org/10.28945/1700

Janosik, S. M., Creamer, D. G., \& Humphrey, E. (2004). An analysis of ethical problems facing student affairs administrators. NASPA Journal, 41(2), 356-374. https://doi.org/10.2202/1949-6605.1338

Johnson, L., Lee, A., \& Green, B. (2010). The PhD and the autonomous self: Gender, rationality and postgraduate pedagogy. Studies in Higher Education, 25(2), 135-147. https://doi.org/10.1080/713696141

Jones, M. (2013). Issues in doctoral studies - Forty years of journal discussion: Where have we been and where are we going? International Journal of Doctoral Studies, 8, 83-103. https://doi.org/10.28945/1871

Katz, R. (2018). Crisis in a doctoral research project: A comparative study. International Journal of Doctoral Studies, 13, 211-231. https://doi.org/10.28945/4044

Kitchener, K. S. (1985). Ethical principles and ethical decisions in student affairs. In H. J. Canon \& R. D. Brown (Eds.), New directions for student services: Applied ethics in student services (pp. 17-29). Jossey-Bass. https://doi.org/10.1002/ss.37119853004

Kitchener, K. S. (2000). Foundations of ethical practice, research and teaching in Psychology. Lawrence Erlbaum. https://doi.org/10.4324/9781410601100

Lee, A. (2008). How are doctoral students supervised? Concepts of doctoral research supervision. Studies in Higher Education, 33(3), 267-281. https://doi.org/10.1080/03075070802049202

Leijen, Ä., Lepp, L., \& Remmik, M. (2016). Why did I drop out? Former students' recollections about their study process and factors related to leaving the doctoral studies. Studies in Continuing Education, 38(2), 129144. https://doi.org/10.1080/0158037X.2015.1055463

Lovitts, B. E. (2005). Being a good course-taker is not enough: A theoretical perspective on the transition to independent research. Studies in Higher Education 30(2), 137-154. https://doi.org/10.1080/03075070500043093

Löfström, E., \& Pyhältö, K. (2012). The supervisory relationship as an arena for ethical problem solving. Education Research International, 2012. https://doi.org/10.1155/2012/961505

Löfström, E., \& Pyhältö, K. (2014). Ethical issues in doctoral supervision - The perspectives of PhD students in the natural and behavioural sciences. Ethics and Behavior, 24(3), 195-214. https://doi.org/10.1080/10508422.2013.830574

Löfström, E., \& Pyhältö, K. (2015). I don’t even have time to be their friend! Ethical dilemmas in PhD supervision in the hard sciences. International Journal of Science Education, 37(16), 2721-2739. https://doi.org/10.1080/09500693.2015.1104424

Löfström, E., \& Pyhältö, K. (2017). Ethics in the supervisory relationship: Supervisors' and doctoral students' dilemmas in the natural and behavioural sciences. Studies in Higher Education, 42(2), 232-247.

https://doi.org/10.1080/03075079.2015.1045475

Löfström, E. \& Pyhältö, K. (2020). What are ethics in doctoral supervision, and how do they matter? Doctoral students' perspective. Scandinavian Journal of Educational Research 64(4), 535-550. https://doi.org/10.1080/00313831.2019.1595711

Löfström, E. \& Pyhältö, K. (2021). How research on ethics in doctoral supervision can inform doctoral education policy. In A. Lee, \& R. Bongaardt, R. (Eds.), The future of doctoral education: Challenges and opportunities. Routledge. https://doi.org/10.4324/9781003015383-30

McAlpine, L. (2013). Doctoral supervision: Not an individual but a collective institutional responsibility. Infancia y Aprendizaje, 36(3), 259-280. https://doi.org/10.1174/021037013807533061 
McAlpine, L., \& Norton, J. (2006). Reframing our approach to doctoral programs: An integrative framework for action and research. Higher Education Research \& Development, 25(1), 3-17. https://doi.org/10.1080/07294360500453012

McAlpine, L., Paulson, J., Gonsalves, A., \& Jazvac-Martek, M. (2012). 'Untold' doctoral stories: Can we move beyond cultural narratives of neglect? Higher Education Research \& Development, 31(4), 511-523. https://doi.org/10.1080/07294360.2011.559199

Mewburn, I., Tokareva, E., Cuthberg, D., Sinclair, J., \& Barnacle, R. (2014). "These are issues that should not be raised in black and white": The culture of progress reporting and the doctorate. Higher Education Research \& Development, 33(3), 510-522. https://doi.org/10.1080/07294360.2013.841649

Murphy, N., Bain, J., \& Conrad, L. (2007). Orientations to research higher degree supervision. Higher Education, 53(2), 209-234. https://doi.org/10.1007/s10734-005-5608-9

Ots, A., Leijen, Ä., \& Pedaste, M. (2012). The relationship between doctoral students' progress in studies and coping with occupational and family responsibilities. In J. Mikk, P. Luik, \& M. Veisson (Eds.), Lifelong learning (pp. 130-145). Peter Lang.

Overall, N. C., Deane, K. L., \& Peterson, E. R. (2011). Promoting doctoral students' research self-efficacy: Combining academic guidance with autonomy support. Higher Education, Research \& Development, 30, 791 805. https://doi.org/10.1080/07294360.2010.535508

Peltonen, J. A., Veikkala, J., Rautio, P. Haverinen, K., \& Pyhältö, K. (2017). Doctoral students' social support profiles and their relationship to burnout, drop-out intentions, and time to candidacy. International Journal of Doctoral Studies, 12, 157-173. https://doi.org/10.28945/3792

Prisacariu, A., \& Shah, M. (2016). Defining the quality of higher education around ethics and moral values. Quality in Higher education, 22(2), 152-166. https://doi.org/10.1080/13538322.2016.1201931

Pyhältö, K., Stubb, J., \& Lonka, K. (2009). Developing scholarly communities as learning environments for doctoral students. International Journal of Academic Development, 14(3), 221-232. https://doi.org/10.1080/13601440903106551

Pyhältö, K., Stubb, J., \& Tuomainen, J. (2011). International evaluation of research and doctoral education at the University of Helsinki - To the top and out to society. Summary report on doctoral students' and principal investigators' doctoral training experiences. University of Helsinki. http://www.helsinki.fi/julkaisut/aineisto/hallinnon julkaisuja 81 2012.pdf

Pyhältö, K., Toom, A., Stubb, J., \& Lonka, K. (2012a). Challenges of becoming a scholar: A study of doctoral students' problems and well-being. International Scholarly Research Network, 12, 1-12. https://doi.org/10.5402/2012/934941

Pyhältö, K., Veikkala, J., \& Keskinen, J. (2012b). Exploring the fit between doctoral students' and supervisors' perceptions of resources and challenges vis-à-vis the doctoral journey. International Journal of Doctoral Studies, 7, 359-414. https://doi.org/10.28945/1745

Rogers-Shaw, C. A., \& Carr-Chellman, D. J. (2018). Developing care and socio-emotional learning in first year doctoral students: Building capacity for success. International Journal of Doctoral Studies, 13, 233-253. https://doi.org/10.28945/4064

Rosenberg, A., \& Heimberg, R. G. (2009). Ethical issues in mentoring doctoral students in clinical psychology. Cognitive and Behavioral Practice, 16, 181-190. https://doi.org/10.1016/j.cbpra.2008.09.008

Sala-Bubaré, A., \& Castelló, M. (2017). Exploring the relationship between doctoral students' experiences and research community positioning. Studies in Continuing Education, 39(1), 16-34. https://doi.org/10.1080/0158037X.2016.1216832

Statistics Estonia. (2019, March 1). In 2018, the average monthly gross wages and salaries were 1,310 euros. https://www.stat.ee/en/uudised/news-release-2019-024

Teeuwsen, P., Ratkovic, S., \& Tilley, S. A. (2014). Becoming academics: Experiencing legitimate peripheral participation in part-time doctoral studies. Studies in Higher Education, 39(4), 680-694.

https://doi.org/10.1080/03075079.2012.729030 
Ethical Perspective on Challenges in Doctoral Education

Vassil, K., \& Solvak, M. (2012). When failing is the only option: Explaining failure to finish PhDs in Estonia. Higher Education, 64(4), 503-516. https://doi.org/10.1007/s10734-012-9507-6

Weise, C., Aguayo-González, M., \& Castelló, M. (2020). Significant events and the role of emotion along doctoral researcher personal trajectories. Educational Research, 1-20.

https://doi.org/10.1080/00131881.2020.1794924

WMA World Medical Association (2013). Declaration of Helsinki. Ethical principles for medical research involving buman subjects. https://www.wma.net/policies-post/wma-declaration-of-helsinki-ethical-principles-for-medicalresearch-involving-human-subjects/

\section{AUTHOR INFORMATION}

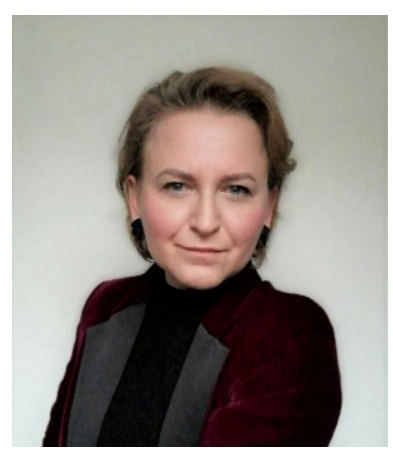

Liana Roos is a doctoral student in the Educational Science program at the Institute of Education at the University of Tartu, Estonia. She earned her master's degree in Adult Education from Tallinn University and a bachelor's degree in Estonian Literature from the University of Tartu.

Liana has worked for 15 years in higher education, and she currently serves as Junior Lecturer in Vocational Education at the Institute of Education and as an Analyst at The Centre for Applied Social Sciences, University of Tartu. Liana teaches classes in pedagogics, academic and reflective writing, adult education, and lifelong learning in her current role. As an Analyst at The Centre for Applied Social Sciences, she contributes to social-scientific application research and analyses. Her thesis aims to understand doctoral students' and supervisors' doctoral education experiences from an ethical perspective.

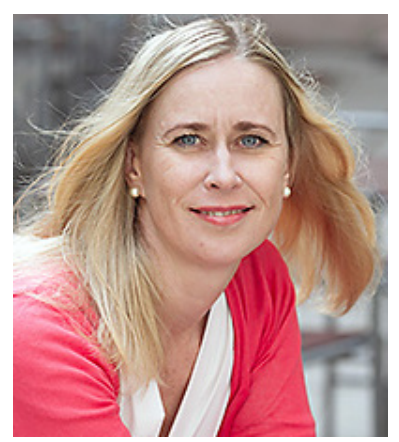

Dr. Erika Löfström holds a $\mathrm{PhD}$ in Educational sciences, and is Professor of Education at the University of Helsinki, Faculty of Educational Sciences, where she is in charge of elementary teacher education for Swedish speakers.

She has a longstanding interest in research ethics and integrity. Her research areas include, among others, research ethics and integrity and related learning and supervision processes. She teaches research ethics/integrity to undergraduate, graduate and doctoral students as well as faculty and experts in these areas. Erika serves on a number of ethics and integrity related boards and committees in Finland, and is a frequently consulted expert internationally. She serves on a doctoral program steering group at her faculty.

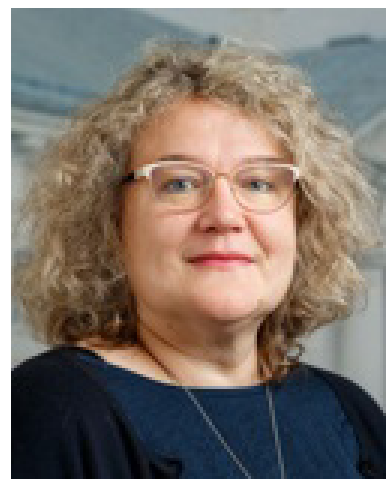

Dr. Marvi Remmik holds a PhD in Educational sciences, and she is Associate Professor of Education at the University of Tartu, Faculty of Arts and Humanities.

Her research interests include professional identity and professional development of university teachers', doctoral supervision and research ethics and integrity. She teaches research methods courses to undergraduate and graduate students. She is involved European Union funded project RITA 4 on ethics and integrity, namely Developing Estonian National System for Monitoring and Supporting Ethics in Scientific Research. 